\title{
Land-Use Change and Livestock Production Challenges in an Integrated System: The Masai-Mara Ecosystem, Kenya
}

\author{
D. M. Nyariki, ${ }^{\mathrm{a}, 1}$, A. W.Mwang'ombe ${ }^{\mathrm{b}}$ and D. M. Thompson ${ }^{\mathrm{c}}$ \\ ${ }^{a}$ Department of Land Resource Management \& Agricultural Technology, ${ }^{b}$ Department of Plant \\ Science and Crop Protection, University of Nairobi, Nairobi, Kenya

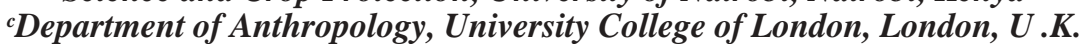 \\ ${ }^{1}$ E-mail: dicksonnyariki@yahoo.com
}

KEYWORDS Commercialization of Pastoral Production. Kenya's Semi-arid Lands. Integrated Land Management. Livelihoods. Pastoral Development. Masai Mara

\begin{abstract}
Participatory rural appraisal techniques and a survey of 100 households were used to evaluate livestock production, and pastoral development of the Maasai in Mara. It was observed that patterns of land-use have principally changed from nomadic pastoralism to sedentary pastoralism, agropastoralism, and, in some cases, pure cultivation. These trends have adversely affected livestock production and the productive capacity of the Mara ecosystem. Diminishing grazing area occasioned by expanding cropping patterns has negatively impacted on vegetation resources and the biodiversity of the ecosystem. It has also increased the intensity of conflict over diminishing land resources. Because the production system is largely subsistence with a strong livestock base, it is further undermined by, among other factors, animal diseases, water scarcity, land individualisation, poor marketing infrastructure, and livestock/wildlife conflicts. Based on the findings of the present study, development approaches need to emphasise integrated livestock and wildlife utilisation, land tenure reforms that embody livestock mobility as a key strategy of optimising the use of transient forage resources, disease control, and development of livestock marketing.
\end{abstract}

\section{INTRODUCTION}

Mara area in Narok District is part of the arid and semi-arid lands (ASALs) that comprise 80 per cent of Kenya's landmass, including rangelands that support extensive livestock operations and wildlife. These areas are home to pastoralists who form 20 per cent of the Kenyan population. Pastoralists occupy 74 per cent of the ASALs and own 60 per cent of cattle and 80 per cent of sheep and goats (GOK 1994).

Livestock production is a major component of the Maasai economy and indeed the Kenyan economy, and goes well beyond direct food production. It contributes about 10 per cent of the gross domestic product (GDP). In pastoral areas such as the Mara region, sales of livestock provide direct cash income to the Maasai pastoralists. Livestock are the living bank for most of these people and in some areas have an important role in the agricultural intensification process through provision of capital for investment. They are also closely linked to the social and cultural lives of most of the Maasai community for whom animal ownership ensures varying degrees of sustainable production and the stability of the domestic economy. Thus, livestock have a multipurpose contribution to meeting food security, agricultural production and social/cultural obligations.

Over the years, patterns of land-use have changed in the ASALs from, principally, nomadic pastoralism to sedentary pastoral and agropastoral production, or to pure cultivation (Muriuki et al. 2005). This trend has in most cases adversely affected livestock production and the productive capacity of these lands. Vast areas of these lands are experiencing some degree of degradation. This has been precipitated by unprecedented population growth, excessive cropping pressure and overgrazing. Overgrazing on these lands is particularly impacting negatively on vegetation resources and biodiversity in general. That is, while moderate grazing is necessary to maintain a range ecosystem, severe grazing affects biodiversity, productivity, carrying capacity and soil fertility, which in extreme cases lead to desertification.

Recent interventions in Mara, such as land privatisation and appropriation to create ranching schemes or to give room to cropping have often generated negative rates of return, and favoured wealthier households (McCathy and Swallow 1999). These interventions have largely replaced nomadic pastoralism, which in many ways has been a successful adaptation to the relatively dry 
and fragile ecosystem. Herders have, as a result, lost prime grazing lands, especially in low-lying plains to create room for the cultivation of maize, wheat and other crops. Unfortunately, cropping in the Mara ecosystem inherently increases the intensity of conflicts, as there is less compatible interaction between crops and wildlife than between livestock and wildlife. As the number of people increases, so does the need for food in terms of livestock products and grain. In the absence of increased livestock production, there is necessarily a reduction in the number of livestock per person, implying that the supply of milk and meat is reduced, increasing the need to supplement household diets.

Declining livestock production and productivity is likely to have devastating implications for many aspects of the Maasai lifestyle. This community is still basically a livestock culture. Thus, if the living standards and food security of the Mara region are to be improved, then livestock productivity has to be increased. Yet, at the same time, it is important that steps taken to raise livestock productivity should be in harmony with the potentially conflicting objectives of conservation and tourism, and possibly grain production. Therefore, the major aim of this study was to investigate how livestock production and productivity could be improved under the framework of a special conservation status as exists within the Mara ecosystem.

\section{METHOD OF STUDY}

A total sample of 100 households was randomly selected for questionnaire interviews in the Mara region during October 1999 to February 2000. Further interviews were done with the Ministry of Agriculture and Rural Development personnel. Group discussions with the local leaders through PRAs were also undertaken. To ensure success of the interviews, enumerators were recruited from the local administrative sub-locations to avoid the language barrier and also ensure co-operation. The areas (clusters) visited for questionnaire interviews were Aitong, Emorijoi, Talek, and Lemek. Homesteads (manyattas) were visited both in the morning and evenings. At the PRA meetings the Maasai elders, in addition to participating in identifying important livestock resources in their location, were asked about the problems related to their livestock, the causes of these problems and priorities for development. Information was also obtained from literature review of government reports and other publications.

\section{RESULTSAND DISCUSSION}

\section{Past and Emerging Production Systems}

About 68 per cent of Narok District is rangeland, which in the past has provided prime grazing for nomadic pastoralism or ranching. Mara area was formerly organised into three group ranches-Lemek, Koiyaki and Olchoro Oirowua-in which livestock were privately owned while grazing land was communal, and capital developments were carried out by the groups. Initially, group ranches were established in Maasai rangelands (in Kaputiei Section of Kajiado District) in accordance with the Land (Group Representatives) Act Cap. 287 of the Laws of Kenya. These ranches were later introduced in other districts of the country including Narok. As a result of the problems that beset the ranches, especially those related to poor management emanating from wrong assumptions, they failed to achieve the intended objectives of improved livestock production, reduced overgrazing and increased environmental conservation. Pressure has since intensified to subdivide the ranches into individual parcels. In Mara, parcelling has been completed and title deeds issued in some areas. The sizes of individual land range between 20ha and 80ha. The effect of land subdivision in this area has been the shifting of the mode of livestock production, which historically has been nomadic pastoralism, to several subsystems. ${ }^{1}$ Table 1 summarises the current modes of production in four areas of Mara-Talek, Aitong (Ngoswani), Lemek (Nkorinkori) and Emorijoi. As can be seen in the table, there are mainly three modes, i.e., full-time livestock husbandry, livestock husbandry with subsidiary cropping, and cropping with or without subsidiary livestock husbandry.

Livestock in Mara were managed by herding. Herding of mature animals was done by adult family members (mainly male but also female) and or hired labour. Young members of the family herd small stock and young cattle (mainly calves). Females, especially the wife or wives of the male livestock owner, did the milking. 
Table 1: Classification of the modes of agricultural production in Mara

\begin{tabular}{|c|c|c|c|}
\hline & & $\begin{array}{l}\text { Area and degree of } \\
\text { mobility }\end{array}$ & \\
\hline Main activity & $\begin{array}{l}\text { No home base; year } \\
\text { round movement }\end{array}$ & $\begin{array}{l}\text { Home base; seasonal } \\
\text { movement of animals }\end{array}$ & Home base; local movements \\
\hline $\begin{array}{l}\text { Full-time livestock } \\
\text { keeping }\end{array}$ & $\begin{array}{l}\text { A few households in } \\
\text { Talek and Aitong }{ }^{\text {a }}(3 \%)\end{array}$ & $\begin{array}{l}\text { Transhumant pastoralists in } \\
\text { Talek and Aitong }(52 \%)\end{array}$ & $\begin{array}{l}\text { Sedentary pastoralists in Talek, } \\
\text { Aitong and Lemek }(20 \%)\end{array}$ \\
\hline $\begin{array}{l}\text { Livestock keeping } \\
\text { with subsidiary } \\
\text { cropping }\end{array}$ & - & $\begin{array}{l}\text { Transhumant agro- } \\
\text { pastoralists in Aitong and } \\
\text { Lemek }(5 \%)\end{array}$ & $\begin{array}{l}\text { Sedentary agro-pastoralists in } \\
\text { Aitong and Lemek }(5 \%)\end{array}$ \\
\hline $\begin{array}{l}\text { Cropping with/without } \\
\text { subsidiary livestock } \\
\text { husbandry }\end{array}$ & - & - & $\begin{array}{l}\text { Maize, beans and/or wheat } \\
\text { farmers in Emorijoi and } \\
\text { Lemek }(15 \%)\end{array}$ \\
\hline
\end{tabular}

\section{Livestock Production}

Breeds and Herd Structure: The main livestock breeds kept in Mara are the Small East African Zebu (SEAZ) or the indigenous Masai cattle, the Small East African Goat (SEAG), and Red (Brown) Masai Sheep and Black-headed Somali Sheep. The Sahiwal and Boran have been introduced in drier areas for beef production, while the Aryshire and the Freisian dairy cattle, and their crosses were being encouraged in the wetter areas with lower disease prevalence and other stresses. The Dorper sheep, the Toggenburg goat and crosses are also increasingly being introduced. The local breeds are, however, well adapted to the relatively harsh environment, infested with tsetse flies and tick-borne diseases in addition to frequent droughts.

Table 2 gives a breakdown of ownership of cattle and small stock. During the dry season (June to October), animals are moved over long distances, and not infrequently across districts (mainly to Trans Mara) to look for water (provided by non-seasonal rivers and springs) and grazing. At this time of the year when animals are trekked over vast distances, most of the households hold back small stock, especially sheep, which can utilise the short stubble of grass.
Table 2: Livestock access per household in Mara by location

\begin{tabular}{lccc}
\hline Area & $\begin{array}{c}\text { Species of } \\
\text { livestock }\end{array}$ & $\begin{array}{c}\text { Average number } \\
\text { of livestock per } \\
\text { household }\end{array}$ & $\begin{array}{c}\text { Per cent } \\
\text { households } \\
\text { owning } \\
\text { livestock }\end{array}$ \\
\hline Talek & Cattle & 157 & 96 \\
& Sheep & 160 & 96 \\
Aitong & Goats & 9 & 96 \\
& Cattle & 177 & 67 \\
& Sheep & 100 & 67 \\
Emorijoi ${ }^{2}$ & Goats & 70 & 67 \\
& Cattle & 0 & 0 \\
& Sheep & 0 & 0 \\
& Goats & 0 & 0 \\
& Cattle & 99 & 93 \\
& Sheep & 117 & 86 \\
& Goats & 64 & 93
\end{tabular}

This is settled area with peasants of Kisii ethnicity (most of them squatters) doing only cropping.

Table 3 presents the herd structure (percentages in brackets) in three areas of livestock production. The table shows that even though more than half of the herd were females, a very small proportion (as low as 10.8 per cent in Talek) of the herd were calves. A large number of cows were dry (as high as 26.3 per cent in Lemek), implying that either conception and calving rates were low or calf mortality was high or both. The total sample shows almost the same structure-

Table 3: Household herd structure ${ }^{a}$

\begin{tabular}{|c|c|c|c|c|c|c|c|}
\hline Area & $\begin{array}{l}\text { No. of } \\
\text { calves }\end{array}$ & $\begin{array}{l}\text { No. of } \\
\text { milk cows }\end{array}$ & $\begin{array}{c}\text { No. of } \\
\text { bulls }\end{array}$ & $\begin{array}{l}\text { No. of } \\
\text { steers }\end{array}$ & $\begin{array}{l}\text { No. of } \\
\text { heifers }\end{array}$ & $\begin{array}{c}\text { No. of } \\
\text { non-milk cows }\end{array}$ & Total \\
\hline Talek & $17(10.8)$ & $18(11.5)$ & $8(5.0)$ & $30(19.1)$ & $34(21.7)$ & $37(23.6)$ & $157(100)$ \\
\hline Aitong & $33(18.6)$ & $35(19.8)$ & $19(10.7)$ & $60(33.9)$ & $37(20.9)$ & $40(22.6)$ & $177(100)$ \\
\hline Lemek & $22(22.2)$ & $22(22.2)$ & $7(7.1)$ & $15(15.2)$ & $20(20.2)$ & $26(26.3)$ & $99(100)$ \\
\hline Total sample & $22(16.3)$ & $23(17.0)$ & $9(6.7)$ & $28(20.7)$ & $29(21.5)$ & $32(23.7)$ & $135(100)$ \\
\hline
\end{tabular}

${ }^{a}$ Separate categories do not add up to 100 per cent because respondents could not give accurate figures. 
16.3 per cent calves, over 50 per cent cows and 23.7 per cent dry cows. With respect to beef production as an objective, these herds were therefore poor producers. However, pastoralists in Aitong area seem to be in possession of better herds as the proportion of calves is much higher (18.6 per cent) and the number of steers is close to what is expected of a fairly market-oriented extensive and low capital beef production system.

Herd and Flock Recruitment: The rate of herd or flock recruitment can be estimated from the calving, lambing or kidding rate. In a herd or flock, recruitment is influenced by the birth of live animals, mortality, abortions and infertility. These factors are in turn affected by the availability of forage, disease and other management variables.

From the data, a herd of 70 mature females (ready for service) is expected to have, on average, 22 calves in a year. This translates to a calving rate of about 30 per cent. Since out of 100 only 30 females, ready for service, calve down a year, it can be estimated that the calving interval per animal was likely to be more than a year in a number of these herds, probably 2-3 years. A few households in fact reported that their cows gave a calf once every two years. The proportion of calves in the herd was quite low (16.3 per cent for the whole sample) despite the high proportion of cows (62.2 per cent for the sample) in the herd. The rate of recruitment was therefore low and could not sustain the cattle population growth to keep up with human population increases in the long term. With no growth in owned herds, commercialisation cannot be improved, unless cattle were to be brought in from outside. Thus per capita availability of milk and meat was bound to decline if improved breeds were not introduced.

For small stock - sheep and goats - the rates of lambing and kidding are naturally higher because their intervals are shorter and twinning is fairly common. For 50 mature females, 38 lambs or kids are given a year, implying that kidding rate may be as high as 76 per cent a year. Even though these were very rough estimates, these rates were much lower than those found in commercial ranches in other parts of Kenya, where calving and lambing or kidding rates of 5070 per cent and over 100 per cent have been recorded respectively (Nyariki 1999).

Milk Production and Marketing: The indigenous Masai cattle produce milk which is mainly used for home consumption. The results indicated that milk output per cow was low. Generally, the indigenous cow is a low milk producer, even though the survey was carried out during the dry season. On average, the number of milked cows per household per day was only 12 , out of 23 cows that had calves. This implied that only about 50 per cent of cows with calves were producing enough milk for the calf and a surplus for household consumption. The average amount of milk produced was 4.3 litres per household per day. With 12 cows being milked, this translates to about 0.2-0.4 litres per cow per day. However, during the rains, the amount of milk produced per cow was said to more than double-to approximately 1-2 litres a day. The figures in this survey compare fairly closely with those obtained by Field, Moll and Sonkoi (1997) in Ngorongoro, Tanzania, who found that during the rainy season, the Maasai of Ngorongoro could on average get 1.1-4.5 litres of milk per cow a day. They also reported that in the arid region of northern Kenya, pastoralists achieved a yearround average of 0.3 litres of milk a cow a day. Figures obtained for the Maasai of Mara compare well with those of earlier studies of the same community. For example, Dahl and Hjort (1976) estimated the production of milk by the Masai zebu at $0.5 \mathrm{~kg}$ per cow per day.

Selling of milk is rarely done, as milk is a staple foodstuff and its production frequently fails to meet household demand. The district livestock reports indicated, however, that milk was normally hawked in small quantities in townships and trading centres when it was produced in excess of household requirements, mainly during the wet season. But these reports also support the findings of the current study; that there was little milk selling going on in the pastoral Maasai areas.

Several constraints were observed to hinder the expansion of milk production and marketing in the study area. The most important include underdeveloped rural markets for milk, keeping of large numbers of cows unsuitable for milk production, shortage of capital to invest in handling and processing facilities and poor and worsening rural infrastructure, particularly roads. There were four small milk co-operatives in the district involved in milk buying and selling. The revival of the giant Kenya Co-operative Creameries (New KCC) has, however, improved milk selling. Milk was also sold by hawking, to hotels and food kiosks in towns and small trading centres, at low prices. 
Meat Production: The composition of the pastoral herd in Mara shows that cattle are kept both for milk and meat, even though milk is the main priority. The average picture was depicted by the herd structure in Table 3. About 21 per cent of the herd was composed of steers and 7 per cent were bulls. This gave 28 per cent of the herd as potential meat source. The data indicated that few of the cattle were consumed at home, based on the low number of cattle slaughter (about two per year in Talek) for home consumption. Steers are sold for slaughter outside the household either within or outside the district.

A large proportion of meat consumed at home came from the small stock, mainly sheep and goats. A number of households reported to have slaughtered 4 sheep and 4 goats every year. These figures look small probably because they do not include the animals consumed after natural mortality. The number of animals consumed at home is thus affected by deaths as most of these animals are also eaten, unless they are too young or are eaten by predators. Natural deaths may constitute up to 50 per cent of household consumption requirement. Table 4 gives the average figures of deliberate home-slaughter of cattle, sheep and goats for the three livestock areas surveyed in Mara.

Table 4: Home-slaughter figures per household per year

\begin{tabular}{|c|c|c|c|}
\hline Area & No. of cattle & No. of sheep & No. of goats \\
\hline Talek & 1.7 & 3.1 & 3.4 \\
\hline Aitong & 0.0 & 3.0 & 3.4 \\
\hline Lemek & 0.0 & 8.5 & 2.0 \\
\hline Total sample & 1.2 & 4.4 & 3.2 \\
\hline
\end{tabular}

Sales of Live Animals for Slaughter: Cattle are occasionally sold for cash, especially during drought, to purchase grains and to also meet other domestic needs such as fees and medical expenses. Sheep and goats are also sold for quick cash, especially when the demand for cash is not much. In fact, unless there is some degree of commercialisation, which according to the survey results seemed to be low, the Maasai prefer selling small stock rather than cattle. It was reported that cattle were sold mainly during the dry season. This is apparently to reduce losses and the vulnerability of households to severe food insecurity during this period. Therefore livestock play an important role in the Maasai food security cycle.
As a depiction of the level of commercialisation, Table 6 shows the number of animals sold and percentages of households selling. The table provides offtake rates for the three surveyed areas and the total sample. ${ }^{2}$ These are very low offtake rates compared with those from commercial ranches in Laikipia, which are between 20 and 25 per cent (Nyariki, 1999). The low offtake rates confirm the historical contention that pastoral production systems are not market-oriented. The figures provided by government officials are normally much higher than what the household survey respondents disclosed as their sales (1-2 per cent per year) (Table 5). It is believed that the local community underestimated the sales. This was because the survey data indicated that they visit cattle markets once a month, on average. The enumerators revealed that the Maasai traders and livestock producers feared being robbed by outsiders if they gave their turnover figures. These robberies are increasingly becoming common after large sales have been made, as insecurity has grown.

A few respondents indicated that animals exchanged hands from one household to another in trade involving middlemen. Some of these middlemen brought in animals from across the border, especially from Tanzania for sale in Kenya, because of favourable price differentials. Most of the cattle from outside end up at the Dagoretti abattoir in Nairobi for slaughter. It is therefore likely that the sales given in the district records do not originate solely in Kenya.

The proportion of steers and male sheep and goats in the Maasai herds and flocks can be used to exemplify the potential for meat production in

Table 5: Household livestock sales in Mara by location

\begin{tabular}{llccc}
\hline Location & $\begin{array}{c}\text { Livestock } \\
\text { species }\end{array}$ & $\begin{array}{c}\text { Number } \\
\text { of live- } \\
\text { stock/sold } \\
\text { household }\end{array}$ & $\begin{array}{c}\text { Per cent } \\
\text { sales } \\
\text { (offtake } \\
\text { rate) }\end{array}$ & $\begin{array}{c}\text { Per cent } \\
\text { house- } \\
\text { holds } \\
\text { selling }\end{array}$ \\
\hline Talek & Cattle & 4.7 & 3 & 87.5 \\
& Sheep & 3.3 & 2.1 & 72 \\
Aitong & Goats & 1 & 11.1 & 66.7 \\
& Cattle & 13 & 7.3 & 50 \\
Lemek & Sheep & 0 & 0 & 0 \\
& Goats & 8.5 & 12.1 & 40 \\
& Cattle & 19.6 & 19.8 & 34.6 \\
Total sample & Sheep & 29 & 24.8 & 16.7 \\
& Goats & 4.3 & 6.7 & 15.4 \\
& Cattle & 10.1 & 7.5 & 57.4 \\
& Sheep & 6.8 & 5.2 & 44.1 \\
& Goats & 2.8 & 6.5 & 39.3 \\
\hline
\end{tabular}


Mara. Table 6 shows this information from the household survey data, using Talek as an example.

Since only 3-4 per cent of males are needed in the herd or flock for breeding, 20 per cent of the herd or flock can be fattened as castrates to provide meat. This then could improve offtake rates.

Table 6: Proportion of steers and mature males of cattle, sheep and goats in Talek

\begin{tabular}{lccc}
\hline Animal & $\begin{array}{c}\text { No. of } \\
\text { animals }\end{array}$ & $\begin{array}{c}\text { No. of } \\
\text { mature males }\end{array}$ & $\begin{array}{c}\text { Per cent } \\
\text { mature males }\end{array}$ \\
\hline Cattle & 157 & 38 & 24.0 \\
Sheep & 160 & 40 & 25.0 \\
Goats $^{\mathrm{a}}$ & 9 & 2 & 22.0 \\
\hline
\end{tabular}

The number of goats was small because most of them had been moved to Trans Mara due to drought.

\section{Livestock Marketing System}

Livestock marketing is considered an essential part of livestock production from pastoral herds because increased production is unlikely to be sustained in these areas unless the product can be traded. Thus, livestock marketing is the ultimate step in the livestock production process. The key to increased production lies in the motivation of producers through an efficient marketing system. Motivation of producers is harnessed by incentives such as credit, inputs and, most importantly, marketing. Herders' income to be used to meet household requirementsclothes, school fees, medication, grain, etc.depends on an efficient marketing system.

Kenya's livestock marketing system evolved from a colonial system designed to safeguard and guarantee European settlers a market free from competition by indigenous Kenyans. By independence, the country inherited a parastatal marketing system that also monopolised the processing of livestock and products (Aldington and Wilson 1968; Mutai 1986). The livestock- oriented parastatals included the Kenya Meat Commission (KMC). There were also functional extra-KMC organised markets and the Livestock Marketing Division (LMD) — a division of one of the government ministries - that provided inlets and outlets of ranch and pastoral stocks.

At independence, the KMC was seen to render adequate marketing services, but later this parastatal deteriorated and it was no longer selfsupporting, and collapsed soon after each of several intermittent efforts to rehabilitate it. (This parastatal has again recently been revived and promises to operate profitably.) The LMD that was, among others, charged with the purchase of low-value stock from the overstocked districts as part of a destocking programme and assisting in putting a floor price for the cattle from pastoral areas, by acting as buyer of last resort, also stopped giving these services. Pastoralists, therefore, depend mainly on livestock dealers to market their animals. In Mara area in particular and Narok District in general, almost all cattle and small stock trade is informal or private. Buying and selling is done at auctions, privately arranged. The government's participation in this is through provision of infrastructure in the form of holding grounds and sale yards. Government auction yards are, however, being shunned by pastoralists as they are not conveniently located. The yards are not secure, and as soon as sales are made some of the pastoralists are attacked and robbed of their sale proceeds. There are also several small slaughterhouses in towns, but these cannot handle large numbers and the main sales are for onward transmission to either Dagoretti in Nairobi or KMC in Athi River.

The problem with private sales is that the process creates room for livestock dealers (middlemen) to exploit pastoralists. This is illustrated by the figures shown in Table 7 (the number of animals sold in brackets). It can be seen that in some cases a producer loses as much as 42 per cent of the potential income per animal

Table 7: Prices (KSh) of cattle, sheep and goats at the farm-gate in Talek and Narok (Ewaso Nyiro) auction yard

\begin{tabular}{lcccrr}
\hline Place & Steers & Bulls & Cows & Sheep & Goats \\
\hline Farm-gate & $9,800(87)$ & $8,000(12)$ & $10,000(9)$ & $1,500(60)$ & $1,028(16)$ \\
Narok & $14,000(1164)^{\mathrm{a}}$ & $14,000(299)$ & $12,000(1164)^{\mathrm{a}}$ & $1,650(1,380)^{\mathrm{b}}$ & $1,300(1,581)$ \\
Difference in price & 4,200 & 6,000 & 2,000 & 150 & 272 \\
\hline
\end{tabular}

The figure in brackets includes both steers and cows.

'Includes only hair and wool sheep. 
(in the case of bulls) when he sells at the farmgate through livestock middlemen. This has tended to keep prices unfairly low. We should, however, not ignore the fact that livestock dealers have provided useful service to pastoralists in the absence of official markets; they assemble livestock from producers that are selling a few animals and are situated far from markets. Instead of trekking a few livestock to Nairobi, Narok Town, Trans Mara or Bomet Districts, which is costly and tedious, the private dealer buys animals at the farm-gate and stocks them in trucks to deficit areas or to slaughterhouses or butchers.

Various factors are negatively affecting livestock marketing in Narok. One of the most serious is deteriorating infrastructure. The roads are very poor and are discouraging truckers to penetrate certain areas located far from market centres. Pastoralists from these areas are then forced to trek their animals over long distances, distances of over $100 \mathrm{~km}$, frequently up to Nairobi. This has several problems. One, animals lose condition and fetch low prices. Two, pastoralists risk being attacked either before or after sales. Three, pastoralists become price-takers when they present animals for sale as their bargaining power is reduced because of difficulties of doing turnround treks with the animals.

Another factor that reduces the efficiency of marketing is the unavailability of trucks. Pastoralists are unable to organise themselves and pool resources to buy their own trucks and this makes them weak in bargaining, so they are easily exploited.

\section{Livestock Diseases}

Control over livestock diseases is essential to successful animal production and marketing. This is as important in pastoral herding as in the more intensive systems of production, as poor animal health is a major constraint to livestock productivity. In pastoral areas, animal health facilities are scanty and where they exist they are concentrated in urban and peri-urban areas. Except for certain disease control programmes (e.g., control of notifiable diseases) that have had spectacular results, most are of questionable effectiveness (Mogoa and Nyangito 1999).

In the Maasai traditional livestock production, livestock heath is mainly affected by long distance movement in search of water and pasture, poor conditions of hygiene in night bomas, predatory attacks, nutritional stresses, and transmission of diseases between the livestock and from wildlife. All these factors influence one another to some extent.

Lessening the effect of disease in pastoral herds has become more difficult as cultivation and other activities have eaten into pastoral territory. In the past, pastoralists could reduce an accumulation of certain predisposing factors to disease by applying nomadic pastoral techniques such as moving between and within seasons to safe areas, and avoiding areas of high disease incidence, such as those infested with tsetse flies. As they continue being squeezed into smaller territory, they face a new situation that requires new approaches to disease control.

District reports catalogue the common diseases in Narok and their impact in relation to the number of animals affected. In the villages, not many households complained of significant losses of animals through diseases during this study. However, the diseases cited as the most common and serious included Foot and Mouth Disease (FMD), Trypanosomosis, Anaplasmosis, Lumpy Skin Disease, Malignant Catarrh, Contagious Bovine Pleuro-pneumonia (CBPP), Caprine Pleuro-pneumonia (CPP), Nairobi Sheep Disease, East Coast Fever (ECF), and Helminthiosis.

A number of the mentioned diseases are notifiable (except CPP, Malignant Catarrh, Anaplasmosis, Nairobi Sheep Disease and Helmithiosis). A large number of them are tickborne and can be controlled easily. There are frequent outbreaks of these diseases. For example, in 1998, there was an outbreak in Mara of FMD, which affected cattle, sheep and goats. This resulted in a number of deaths. Vaccination for prevention was undertaken and quarantine was effected to stop the spread of the disease.

Disease control efforts, especially prevention, in the area are not impressive. There are, for example, 127 dips in the district, but only 50 (only those supported by the county council) are currently functioning. These dips are also not well distributed. Tick-borne diseases (both internal and external) as a result have become endemic. There is usually an upsurge of these diseases during the wet season as grass is one of the main habitats of ticks. Also, virtually no control of Trypanosomosis is instituted, making it endemic as well. The two groups of disease dominate clinical cases in Mara. Most pastoralists 
now depend mainly on treatment rather than prevention of these diseases and costs of control are high. Veterinarians have taken advantage of this and are charging exorbitantly for treatments. It was reported that the veterinarians also take the pastoralists advantage of by cheating on diagnosis and medicines, again leading to an escalation of treatment costs.

\section{Other Factors Affecting Livestock Development}

Water Availability: As in many other ASAL areas, water is a scarce resource in many parts of Mara. Few areas in Narok District can be said to be suitable for rain-fed agriculture based on the annual average rainfall and number of days of rain. Where long-term average annual rainfall is below $750 \mathrm{~mm}$, these areas are better used for grazing. In 1998, however, some stations in the district recorded impressive amounts of rain, but it should be remembered that this was an extraordinary year of the El Nino phenomenon. The annual average for that year was $1,028 \mathrm{~mm}$ compared to an average of about $626 \mathrm{~mm}$ in 1997 , indicating that most of the district is best used as rangeland. Even as a livestock zone, frequent droughts take a toll on the condition and numbers of animals. Usually the breeding herd (cows and young calves) are most affected.

Rainfall affects the seasonality of water sources and quantities available from these sources. As human population rises, so does the need for more water, both for the people and their animals. Localised limited supplies of water lead to overgrazing and trampling by cattle with a serious negative environmental impact.

Land Individuation and Cultivation: By the nature of pastoral production, large territories are required for efficient management of livestock. Pastoralism sets a unique relationship between people, livestock and land. As the main components of land - grass, shrubs, water-vary both in time and space, mobility is an important aspect of pastoral production (Swift 1977). That is, opportunism and tracking become key resource use strategies (Sandford 1983) with livestock mobility flattening peaks in grazing pressure and allowing the use of feed resources that are periodically available (De leeuw et al. 1999). Mobility does take place too to take advantage of other situations, such as exploitation of some specific resources (e.g., available water or salts), or provide escape from hazardous situations such as increased incidences of disease. Pastoralists thus adapt nomadically to their environment when their adaptation requires movement beyond their home base or when alternatively there is a greater advantage in maximising mobility. Mobility necessitates reciprocal user rights of communally owned resources. This quid pro quo exchange of use rights is the basis for the non-exclusive tenure and land-use regimes characteristic of pastoral Africa (Behnke 1993).

The Maasai pastoralists of Narok (and those in Kajiado and Samburu Districts), who for centuries have relied on pastoralism for subsistence seem to be at a crossroads. Their customary owned land that possesses common pool resources-involving the age-old sharing of resources by the family unit through to clans and the Maasai community-have been or are being privatised through sub-division into individual holdings. The provision of title deeds has opened up large tracts of land that has been supporting large numbers of livestock to speculators and cultivators.

The pressure to sub-divide land came from Maasai political leaders who saw a threat to communal ranch land from non-Maasai communities. They supported the parcelling of land among members of group ranches. This was resisted by a few, especially the young people, who feared they may become landless through the new arrangement. But they did not succeed because the government, as the trustee, gave in to pressure. The policy makers then focussed on agriculture and had little regard for the Maasai pastoral production. Cropping was therefore given priority on pastoral land.

The failure of communal ranching stemmed primarily from the fact that the Maasai who were to be settled into organised farming did not embrace the concept. Also, anticipated benefits of having commercial stocks did not improve and breeding of quality cattle did not increase. Common resources and facilities-cattle deeps, water holes and access pastures-were too a constant source of conflicts, and management committees lacked popular mandate.

Privatisation into smaller individual holdings is for the registered members of the group ranches. Registration was stopped in the early 1980s, when most of the registers were closed. There were large loans from the Agricultural Finance Corporation (AFC) that had to be paid 
before issuance of title deeds could take place. The loans were used to purchase livestock and put up facilities such as dips. Group ranch committees on behalf of the members whose land was used as collateral guaranteed the loans.

Soon after sub-division, land was no longer under the care of the community and the neighbouring communities started purchasing the parcels from individuals. In Mara, large areas have already been sub-divided and in some other parts sub-division is still continuing. In the whole of Narok District, over 50,000 hectares of the subdivided land has already been sold to peasant farmers from mainly the Kisii, Kalenjin and Kikuyu communities. More of the rest is under short- or long-term leases for commercial wheat and barley farming (Sunday Standard, 10th October 1999). Some peasants have settled as squatters under an agreement with the Maasai landowners, akin to the 'feudal' system, where the peasant cultivators give a portion of the harvest to the landowners. According to some of the respondents in Mara, settlements such as these have been the source of tribal conflicts in the recent past.

Large-scale wheat, barley and maize farming has pushed pastoralists further into marginal areas as more land is put under crops. With no reduction in the herd sizes, this exposes the land to overuse and degradation. Another negative impact regarding cultivation is that when the fertility of cultivated areas goes down and the lessees are not realising profits, they abandon the farms and open up new sites. The abandoned sites are then exposed to erosion. In addition, these sites, after having been cleared of natural vegetation including grass, have their soil seed banks depleted through the use of herbicides. It then takes long before vegetation appears so that they may be useful once again to the pastoralists. This is not new or unique to Mara. It has happened in other dry areas, especially where recess or flood irrigation is practised, such as the north-eastern parts of Ethiopia (Alemu et al. 1999) and Kenya. Furthermore, when land is at stake for cultivation, no reference is made to agricultural technical persons as to the suitability of the soils, topography and location with respect to water catchments (GOK 1999). As a result gullies are now a common feature in many areas.

What is emerging from the sub-division of group ranches is that even the Maasai have adopted agro-pastoralism, after running into difficulties with sedentary pastoralism. Rain-fed agriculture mainly through farming associations is taking root, especially after the bumper harvest occasioned by the El Nino rains of 1998. It is now being realised that this was short-lived experience.

One major problem related to livestock/wildlife management vis-à-vis individualisation of land is that the Mara area serves as a wildlife dispersal area. How can cultivation be avoided in the future in this area as a conservation policy? True, this was private land under group ranching even before individualisation. But it is much easier to implement conservation policy under group interests rather than under many and differing individual interests. Yet another potential problem is that when land was being individualised the creation of corridors to water points, salt licks and other public utilities like dips was ignored. In fact, some water resources and salt licks were privatised. Issues related to future access to these utilities and natural resources are potentially explosive. A related issue is that of livestock mobility. As alluded to earlier, mobility is an important tenet of pastoral production. How mobility will be ensured in future under individualised land tenure system remains a big question.

Wildlife: Conflicts between pastoralists and their livestock on the one hand and wildlife and conservationists on the other are not new. For example, the Maasai and Parakuyo of Tanzania took their government to court over their expulsion and exclusion from the Mkomazi game reserve (Rogers et al. 1999). Creation of game parks/ reserves deprives pastoralists of important dry season grazing and, thus, precipitates conflict. Mara area has not been left out in this respect. Several deaths of livestock and even losses of human lives in the recent past have been attributed to wildlife. The most common losses of livestock were those related to predation by lions and other animals. Loss of human life (it was estimated at 7 people in Mara in one year during this study) was associated with elephant attacks.

Wildlife reduce forage and water available to livestock. The elephant, wildebeest and zebra are heavy consumers of pasture. In addition, elephants destroy forests (subjecting land to erosion), manyattas, and night bomas. Transmission of certain livestock diseases is aided by wildlife. Control of diseases is also made 
difficult as vaccination of wildlife cannot be undertaken, nor can quarantines be imposed on them. Thus the health of the animals is affected and the veterinary care costs are escalated. Furthermore, wildlife increase costs of maintaining manyattas, fences of bomas and other structures, at least indirectly through labour and vegetation.

With reduced poaching in the last few years, there has been an upsurge of wildlife numbers, especially the elephants. This has worsened the negative impact on livestock. For those households practising agro-pastoralism, including farming associations, costs are being incurred in direct destruction of crops and fences. This is particularly serious at the geographical interface between the Mara Game Reserve and individualised cropland. Here elephants are destroying even strong electric fences.

The indirect influence of wildlife conservation on livestock production in areas adjacent to Mara Game Reserve is that group and individual landowners have turned their land into wildlife sanctuaries and have developed tented camps. This may replace pastoralism in the long-run in these areas.

Whilst there are many negative impacts of wildlife, there are also positive ones. The funds collected from tented camps can be used to improve on livestock. This money can also be viewed as compensation for wildlife use of land resources. Pastoralists are further benefiting directly by forming local bodies that collect fees from tourists. There are two such bodies in Mara-Koiyaki-Lemek and Olchoro Oirowua Wildlife Management Trusts - that derive direct benefits by levying fees for viewing and birdshooting, among other activities. In view of these benefits, there are two possible outcomes regarding the direction of livestock development vis-à-vis wildlife conservation. One may be that the returns obtained from conservation are invested in livestock production, thus improving pastoralism. However, if it turns out that conservation is more lucrative than livestock production, this might be a threat to the future of pastoralism.

Those who support the use of rangelands for wildlife and livestock, rather than livestock alone (see, for example, Hopcraft 1988; Pratt and Gwynne 1977), centre their arguments on the ecological advantages of wildlife. The advantages include a more balanced use of vegetation, leading to more efficient use of available grass, herbs and trees; less tracking and trampling on land due to lower water requirements of game; and the maintenance of species diversity and the accompanying symbiotic relationships vital to the maintenance of the land resource itself. Additionally, cattle, for example, use 50-70 litres of water per animal daily while game animals use only a fraction of this amount. Some species actually require no water at all.

Insecurity: Security in the range areas is the cornerstone of future development. Livestock keepers are under constant threat of attacks by cattle raiders who in many cases also take human life. Theft occurs among the Maasai themselves but on a small scale. The neighbouring Kalenjin, Kisii and Kuria communities undertake major raids. The raids together with land conflicts have on many occasions caused widespread tribal wars (clashes), such as the one that occurred in 1991. In recent times, raids have assumed a dimension traditionally not existing; raiding has become predatory where sophisticated weapons are employed, causing massive destruction of both human life and property. Thus, addressing insecurity becomes critical to ensuring sustainability of the production system. This rests with the government as its primary responsibility.

\section{CONCLUSION}

The foregoing results and discussions indicate that to achieve greater individual and local (rural) development in the Mara region, there is a need to develop the most important means of livelihood: livestock production. However, this should take into consideration conservation efforts, as this is an important conservation area. Livestock development should involve improving livestock production to enable the Maasai community to use livestock as a source of survival and wellbeing, together with all the other activities that make up the livelihood systems of the Maasai, who operate in an economy with a strong subsistence component.

In addition to raising livestock production for the market, livestock development planning should also ensure corresponding development measures and policies that would help livestockkeepers to meet their own objectives - since they are the ones who make production decisions. Past records of livestock development suggest that many policies were made and projects initiated which were based on false assumptions 
about livestock-keepers' aims and objectives and about how decisions are made by the production units: the livestock keeping households. With a focus on people-oriented development, the functions of livestock in the local economy can be examined and something can be learnt from the systems of livestock production, within the livestock-wildlife-human interaction, on how to make optimal use of local renewable resources.

\section{ACKNOWLEDGEMENTS}

We wish to thank the African Conservation Centre (ACC) for the logistical and financial support of this study. However, the Centre does not necessarily support the views expressed in this paper, much less bear responsibility for any errors.

\section{NOTES}

1. Pastoralism is a production as well as a socio-cultural system consisting of an interaction between herders, animals and a given mode of resource management (Swift, 1977)

2. Note that off-take rates were calculated by considering livestock numbers rather than livestock units. This is a crude way of estimating off-take. Strict methods of doing this are discussed by Nyariki et al. (2005, pp.121) and Nyariki (2008).

\section{REFERENCES}

Aldington JJ, Wilson FA 1968. The marketing of beef in Kenya. Occasional Paper No. 3, Institute for Development Studies (IDS), Nairobi.

Alemu DT, Farah KO, Nyariki DM 1999. Influence of settlements on land-use and vegetation in the rangelands of north-eastern Ethiopia: Application of aerial photographic technique. Journal of Human Ecology, 10(5-6): 349-356.

Behnke R 1993. Natural resource management in pastoral Africa. In: D Stiles (Ed.): Listening to the People: Social Aspects of Dryland Management. Proceedings of a UNEP Conference, $14-18^{\text {th }}$ Dec. Nairobi.

Dahl G, Hjort A 1976. Having Herds: Pastoral Herd Growth and Household Economy. Stockholm Studies in Social Anthropology, Stockholm, Sweden.

Daily Nation 1998. Daily periodical, Nairobi (11 ${ }^{\text {th }}$ August.

De Leeuw PN, Hiernanx P, Miheso VM 1999. Grazing Pressure in Sub-Saharan Africa: An Historical Perspective. Nairobi: ILRI.

Field CR, Moll G, Sonkoi C 1997. Livestock development. In: DM Thompson (Ed.): Multiple Land-Use: The
Experience of the Ngorongoro Conservation Area, Tanzania. Gland and Cambridge: IUCN.

GOK (Government of Kenya) 1994. National Development Plan, 1994-1996. Office of the Vice President and Ministry of Planning and National Development, Nairobi.

GOK (Government of Kenya) 1999. Narok District Annual Report. Department of Agriculture, Ministry of Agriculture, Narok, Kenya.

Hopcraft D 1988. The Ecological and Economic Validity of Wildlife in the Semi-Arid tropics. Scientific Review on Arid Zone Research, 8. Bombay: Scientific Publishers.

Mogoa EM, Nyangito MM 1991. Constrains to delivery of animal health services in the pastoral areas of Kenya: A review. African Pastoral Forum, No. 20.

Muriuki GW, Njoka TJ, Reid RS, Nyariki, DM 2005. Tsetse control and land-use change in Lambwe valley, south-western Kenya. Agriculture, Ecosystem and Environment, 106: 99-107.

Mutai AM 1986. Livestock marketing in support of district focus strategy. Paper for an Induction Course of Veterinary and Agricultural Officers, by the Ministry of Agriculture and Livestock Development, Nairobi, November - December, 1986.

Nyariki DM 1999. Planning projects in the rangelands: A lecture manual (Mimeo). Department of Range Management, University of Nairobi.

Nyariki DM 2008. Price response of herd off-take under market liberalisation in a developing cattle sector: Panel analysis applied to Kenya's ranching, Environment and Development Economics, (in press)

Nyariki DM, Makau BF, Ekaya WN, Gathuma JM 2005. Guidelines for Emergency Livestock Off-take Handbook. Nairobi: ALRMP and AGREF, pp.121.

Nyariki DM, Munei K 1993. Economic factors affecting the level of beef production from ranching: An example of Kenya's cattle sector. East African Agricultural and Forestry Journal, 59(2): 163-170.

Nyariki DM, Wiggins S 1999. Livestock as capital and a tool for ex-ante and ex-post management of food insecurity in semi-traditional agro-pastoral societies: An example from south-east Kenya. Journal of Social Sciences, 3(3): 117-126.

Pratt DJ, Gwynne MD 1977. Rangeland Management and Ecology in East Africa. London: Hodder and Stoughton.

Rogers DJ, Brockingtom D, Kiwasila H, Homewood J 1999. Environmental awareness and conflict genesis: People versus parks in Nkomazi Game Reserve, Tanzania. In: T Granfelt (Ed.). Magazine the Globalised Environment: Local Sharpies to Secure Livelihood. London: IT Publications.

Sandford S 1983. Management of Pastoral Development in Third World. London: John Wiley and Sons.

Sunday Standard 1999: Special report. Nairobi: Daily Periodical, $10^{\text {th }}$ October 1999 , pp. 14-15.

Swift J 1977. In defence of nomads. Mazingira, 2: 2630. 